TAXONOMY AND NOMENCLATURE

\title{
Couples in phoretic copulation, a tool for male-female association in highly dimorphic insects of the wasp genus Dissomphalus Ashmead (Hymenoptera: Bethylidae)
}

\author{
Celso O. Azevedo ${ }^{1^{*}}$, Wesley D. Colombo ${ }^{1}$, Isabel D.C.C. Alencar ${ }^{1}$, \\ Chirlei D. de Brito ${ }^{1} \&$ Cecilia Waichert ${ }^{1}$
}

\author{
${ }^{1}$ Departamento de Ciências Biológicas, Universidade Federal do Espírito Santo. Avenida Fernando Ferrari 510, \\ Goiabeiras, 29075-910 Vitória, ES, Brazil. \\ “Corresponding author. E-mail: bethylidae@gmail.com
}

\begin{abstract}
It is difficult to make reliable sex associations in several species of Hymenoptera due to sexual dimorphism. Only a few species of the flat wasp genus Dissomphalus Ashmead, 1893 have had their sexes associated, since females are rarely collected and differ morphologically from their conspecific males. Collecting couples during their phoretic copula is difficult, but it is the most reliable way to associate the sexes in Dissomphalus. Herein, we associate the sexes and discuss the mating system based on couples of six Dissomphalus species collected during copulation: D. bisserratus Azevedo, 1999, D. connubialis Evans, 1966, D. rettenmeyeri Evans, 1964, D. simulatus (Evans, 1969), comb. nov., D. mendicus Evans, 1969, and D. firmus Redighieri \& Azevedo, 2006. The females of the latter three are described for the first time. The distribution of two species is expanded. Apenesia simulata Evans, 1969 is transferred to Dissomphalus and is now D. simulatus comb. nov. Finally, we briefly discuss the genital structures used during phoretic copulation, analyzing the male and female genitalia in copulation. During copulation, the mating female is attached to the male only by the genitalia and is apparently grasped by muscles attached to the male's metasoma.
\end{abstract}

KEY WORDS. Couple, Neotropical region, taxonomy.

Representatives of Pristocerinae are highly dimorphic: males are larger and winged, whereas females are smaller, wingless, and have vestigial or reduced eyes (AzEvedo 1999, Terayama 2001). At least three genera of Pristocerinae (Apenesia Westwood, 1874, Dissomphalus Ashmead, 1893, Pristocera Klug, 1808) perform phoretic copulation, during which the male carries the female suspended by his genitalia for long distances and periods (EvANs 1969). Females are cryptic, and are rarely collected with traps that intercept flying insects. On the other hand, males are commonly trapped by these kinds of traps and are better represented in collections. Unfortunately, few couples are captured during phoretic copulation. The underrepresentation of Pristocerinae females in collections has resulted in taxonomic studies based almost exclusively on males. Additionally, Pristocerinae females are difficult to separate taxonomically.

Dissomphalus is a cosmopolitan genus of Pristocerinae with 288 species, of which 258 are known only from males, 18 only from females, and 12 from both sexes (personal database).
Seven of these 11 species with both males and females described were found in copula, the remaining four associations were not justified in the original papers. We believe that these associations were established when the male and female were collected from the same locality. Couples captured in copula are the best evidence of conspecificity (GoRDH 1990). In Dissomphalus, inter-sexual variation in body structures might be correlated with different parasitoid habits, dispersal, and mating ability. The specific morphology of females allows them to search for hosts and survive in their cryptic environment, e.g., bark, seed, and grain. The winged male has well-developed eyes and ocelli and performs the species' dispersion (Evans 1969). A single coupled bethylid wasp association has been tested using other tools such as DNA barcoding (see SAWADA et al. 2014).

The goals of this study are to describe and associate females of Dissomphalus based on capture in copula; to provide new records of occurrence for the genus; and to briefly discuss the mechanisms that couple the genital structures in Dissomphalus. 


\section{MATERIAL AND METHODS}

The examined material was provided by the following institutions: CNCI - Canadian National Collection of Insects, Ottawa, Canada; IBGE - Instituto Brasileiro de Geografia e Estatística, Brasília, Brazil; and UFES - Bethylidae Collection of Universidade Federal do Espírito Santo, Vitória, Brazil.

The nomenclature of the integument generally follows HARRIS (1979). The terminology used for the external morphology generally follows Evans (1964), and for the genitalia follows SNODGRASS (1941).

The couples were detached using glass excavated under a stereomicroscope with the aid of forceps and stylet. The specimens were photographed under a Leica Z16 APO stereomicroscope coupled to a Leica DFC 2 video camera by Leica Microsystems. Two different software programs were used to combine the images: Leica Application Suite V3.6.0 by Leica Microsystems (Switzerland) and Helicon Focus (Helicon Soft).

\section{TAXONOMY}

\section{Dissomphalus simulatus (Evans, 1969), comb. nov.}

Figs. 1-3

Apenesia simulata: Evans, 1969: 6-7, 21-22.

Description of female (in copula) (Fig. 1). Length of body $1.4 \mathrm{~mm}$. Color. Head, mesonotum, metanotum, clypeus, palpi, antenna, leg and petiole light castaneous and eyes castaneous. Head (Fig. 2) 1.58x as long as wide, sides parallel, slightly convex. Frons polished, punctures minute and sparse. Mandible with four apical teeth, two lower ones large. Clypeus with narrow and rounded median lobe, median carina wide basally. First four antennal segments in ratio of 9:2:1:1, segment XI 0.6x as long as wide. Eye with about eight facets, subcircular, distant from mandible 3.0x its length. Vertex concave, corner rounded, occipital carina visible in dorsal view. Gena $0.52 x$ length of head. Mesosoma (Fig. 3) polished, punctures minute and sparse. Pronotal collar $0.22 \mathrm{x}$ length of pronotal disc, this $1.28 \mathrm{x}$ as long as wide. Mesoscutum $0.33 \mathrm{x}$ length of pronotal disc, posterior margin straight. Propodeal disc long, $1.42 \mathrm{x}$ as long as wide, spiracle with lower rim outside of propodeal disc embraced by lateral margin and closed to anterior margin. Legs polished, profemur 2.0x as long as wide, mesotibia without spurs. Metasoma polished, cross section subcircular. Petiole long and rugose.

Material examined. Bolivia, Cochabamba $(105 \mathrm{~km}$ E, Rio Carmen Mayo, low cloud forest, $17^{\circ} 08^{\prime} 47^{\prime \prime}$ S, 65 $\left.43^{\prime} 55^{\prime \prime} \mathrm{W}\right), 1$ male and female in copula, 6-8.ii.1999, flight interception trap, F. Génier leg. (CNCI).

Remarks. This species was known only from males from Argentina. It is now recorded for the first time from Bolivia and the female is described.

Apenesia simulata is here transferred to Dissomphalus since both males and females have the general body design and char- acters that fit perfectly the current concept of Dissomphalus. The aedeagus of $A$. simulata is divided into ventral ramus and dorsal body, which represent the main synapomorphy of the genus (AzEvedo 2003). Although the males of $A$. simulata do not have tergal process, the easiest and most used character to recognize Dissomphalus species, the absence of this structure, has been reported for several species of the genus, such as $D$. incomptus Evans, 1964 by Evans (1964) and D. jubus Mugrabi \& Azevedo, 2013, D. kelsus Mugrabi \& Azevedo, 2013, D. turinus Mugrabi \& Azevedo, 2013 and D. lidinus Mugrabi \& Azevedo, 2013 by Mugrabi \& Azevedo (2013). A variation has also been observed in D. microstictus Evans, 1969, which may or may not have the tergal process (AlenCAR \& AzEvedo 2008).

The male of $D$. simulatus is similar to $D$. peculiaris Redighieri \& Azevedo, 2006 by having the clypeus broadly projected forward; mandible tetradentate; apex of paramere straight and base of dorsal margin wide, ventral ramus with base wide, gradually narrowing into a rounded apex; notaulus complete; metasomal tergite II without tergal process; aedeagal ventral ramus twisted apically and outer lobe of dorsal body with a tooth directed downward. Conversely, D. peculiaris has notaulus incomplete; metasomal tergite II with a pair of lateral depressions, each with a pit bearing a small tuft of erected setae; aedeagus with ventral ramus laminar, not twisted and outer lobe of dorsal body rectangular, without tooth, directed downward.

In both sexes of $D$. simulatus comb. nov. the mandible is tetradentate, the vertex is concave with rounded corners, and the punctures on the head and mesosoma are minute.

\section{Dissomphalus mendicus Evans, 1969}

Figs. 4-6

Description of female (in copula) (Fig. 4). Length of body $2.1 \mathrm{~mm}$. Color. Body light castaneous, head and antenna light castaneous, clypeus and palpi darker, eye black, mesonotum, metanotum and leg light castaneous, petiole dark castaneous. Head (Fig. 5) 1.28x as long as wide, side parallel, slightly convex. Frons densely coriaceous, punctures large, dense and shallow, separated by $1.0 x$ their diameters. Mandible with two apical teeth, lower one larger. Clypeus with wide trapezoidal median lobe, median carina very high, wide basally. First four antennal segments in ratio of 30:6:5:5, segment XI $0.5 \mathrm{x}$ as long as wide. Eye with about eight facets, subcircular, distant from mandible $1.5 \mathrm{x}$ its length. Vertex concave, corner angulate, occipital carina visible in dorsal view. Gena $0.42 x$ length of head. Mesosoma (Fig. 6) coriaceous, punctures very shallow; pronotal collar and propodeum coriaceous. Pronotal collar $0.32 \mathrm{x}$ length of pronotal disc, $1.19 \mathrm{x}$ as long as wide. Mesoscutum $0.48 \mathrm{x}$ length of pronotal disc, posterior margin convex. Propodeal disc long, $1.62 \mathrm{x}$ as long as wide, spiracle with low rim outside of propodeal disc embraced for lateral margin and near of anterior margin. Legs weakly coriaceous, setae dense, profemur $2.0 \mathrm{x}$ as long as wide, mesotibia without spurs. Metasoma polished, cross section subcircular. Petiole long and rugose. 

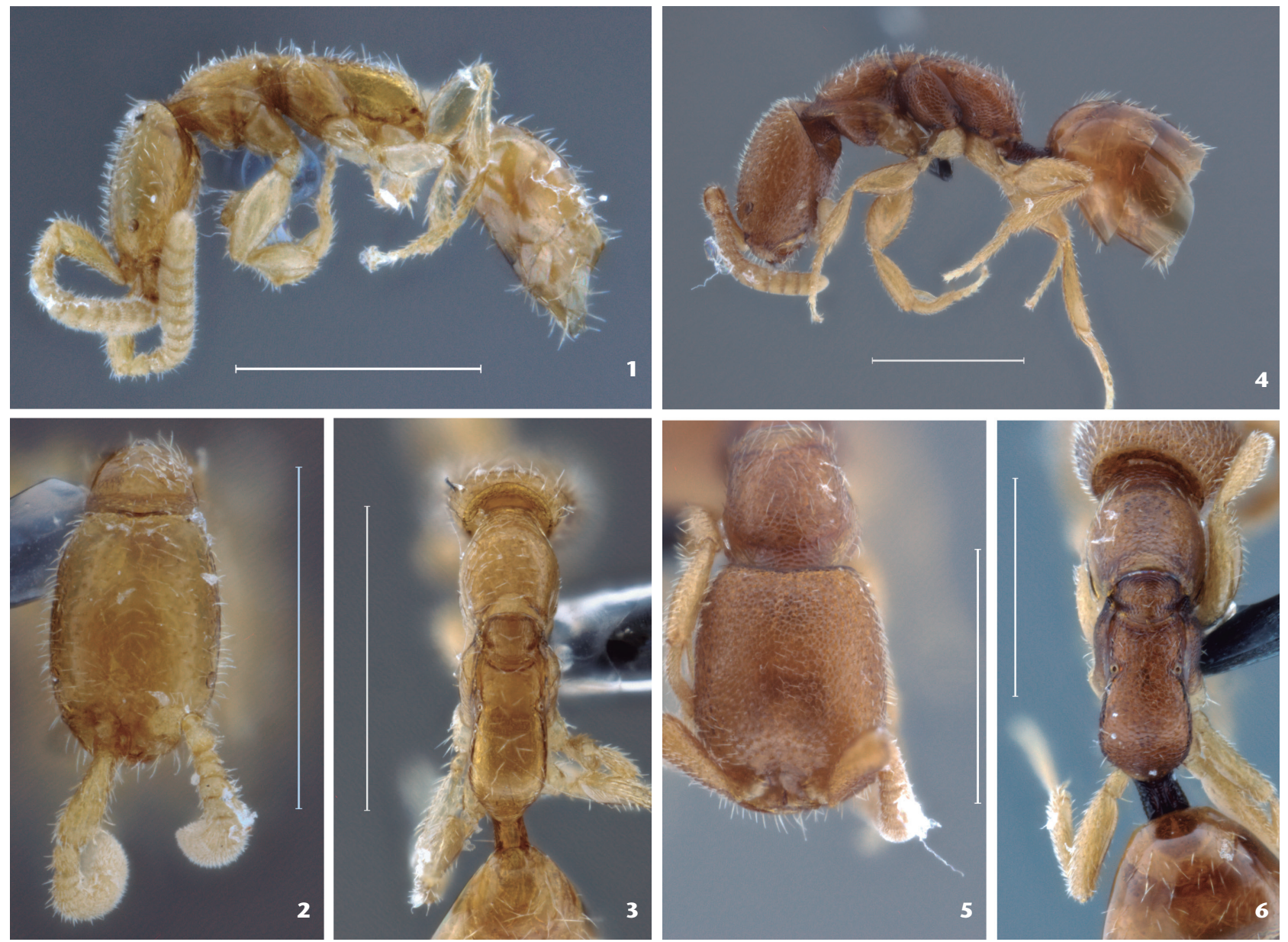

Figures 1-6. (1-3) Female of Dissomphalus simulatus from Bolivia: (1) habitus in lateral view; (2) head in dorsal view; (3) mesosoma in dorsal view. (4-6) Female of Dissomphalus mendicus from Brazil, Distrito Federal: (4) habitus in lateral view; (5) head in dorsal view; (6) mesosoma in dorsal view. Scale bars: $500 \mu \mathrm{m}$.

Material examined. BRAzIL, Distrito Federal: Brasília (Reserva Ecológica do IBGE, $\left.15^{\circ} 55^{\prime} 58^{\prime \prime} \mathrm{S}, 47^{\circ} 51^{\prime} 02^{\prime \prime} \mathrm{W}\right), 3$ males and females in copula,1-8.viii.1980, 2-9.x.1981, 7-15.iv.1982, window trap, J. Dalmáceo leg. (IBGE).

Remarks. This species was known only from males from Argentina. It is now recorded for the first time from Brazil and the female is described. Dissomphalus connubialis Evans, 1966 and D. microstictus also occur in northern Argentina and central Brazil (Brazilian savannah vegetation). Dissomphalus cornutus Evans, 1964 and D. bispinulatus Evans, 1969 occur in northern Argentina and the Brazilian savannah area of the state São Paulo. Thus, the discovery of D. mendicus in central Brazil does not represent a new pattern of distribution of Dissomphalus throughout the Neotropical region.

In both sexes of $D$. mendicus the mandible is bidentate, the vertex is concave with corners angulate, and the head, pronotum and mesoscutum are coriaceous.

\section{Dissomphalus firmus Redighieri \& Azevedo, 2006}

Figs. 7-9

Description of female (in copula) (Fig. 7). Length of body $1.6 \mathrm{~mm}$. Color. Body light castaneous, head and antenna light castaneous, clypeus and palpi paler, eye black, mesonotum, metanotum and leg light castaneous, petiole dark castaneous. Head (Fig. 8) 1.4x as long as wide, side parallel, slightly convex. Frons densely coriaceous, punctures large, shallow, irregularly dense. Mandible with four apical teeth, lower one larger. Clypeus with wide trapezoidal median lobe, median carina very high, wide basally. First four antennal segments in ratio of 5:1:1:1, segment XI $0.5 \mathrm{x}$ as long as wide. Eye with about four facets, circular, distant from mandible $0.6 \mathrm{x}$ its length. Vertex concave, corner angulate, occipital carina visible in dorsal view. Gena $0.9 \mathrm{x}$ length of head. Mesosoma (Fig. 9) coriaceous, punctures shallow; pronotal collar and propodeum coriaceous. Pronotal collar $0.4 \mathrm{x}$ 

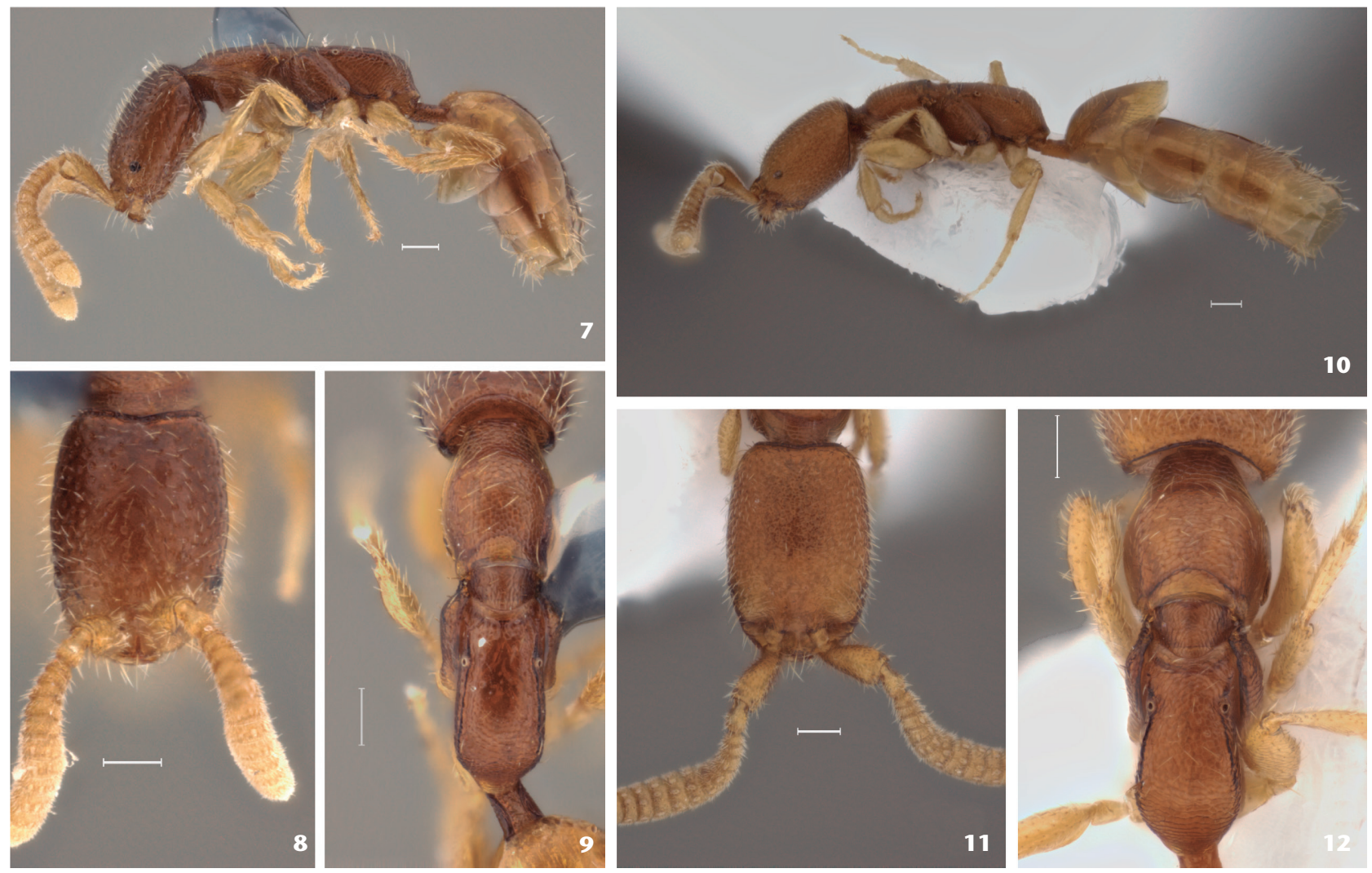

Figures 7-12. (7-9) Female of Dissomphalus firmus from Panama: (7) habitus in lateral view; (8) head in dorsal view; (9) mesosoma in dorsal view. (10-12) Female of Dissomphalus rettenmeyeri from Panama: (10) habitus in lateral view; (11) head in dorsal view; (12) mesosoma in dorsal view. Scale bars: $100 \mu \mathrm{m}$.

length of pronotal disc, this $1.2 \mathrm{x}$ as long as wide. Mesoscutum $0.3 x$ length of pronotal disc, posterior margin convex. Propodeal disc long, 1.5x as long as wide, spiracle with low rim outside of propodeal disc embraced for lateral margin and near of anterior margin. Legs weakly coriaceous, setae dense, profemur $2.0 \mathrm{x}$ as long as wide, mesotibia without spurs. Metasoma polished, cross section subcircular. Petiole long and rugose.

Material examined. BrazIL, Espírito Santo: Cariacica (Reserva Biológica de Duas Bocas), 1 male and female in copula,12-13. iii.2009, yellow pan trap, BF Santos \& eq. leg. (UFES).

Remarks. This species was known only from males from Brazil, states of Espírito Santo, São Paulo, Paraná and Santa Catarina. The female is described here. Both males and females have the mandible tetradentate, the vertex concave with corners angulate and the head, and the pronotum and the mesoscutum coriaceous.

\section{Dissomphalus rettenmeyeri Evans, 1964}

Figs. 10-13

Description of female (in copula) (Fig. 10). Length of body $2.3 \mathrm{~mm}$. Color. Body castaneous; legs light castaneous.
Head (Fig. 11) 1.42x as long as wide, sides parallel, slightly convex. Frons coriaceous, punctures median-sized, shallow, irregularly dense. Mandible with four apical teeth, two uppermost small, two lowermost large. Clypeus with median lobe subtrapezoidal and short, median carina incomplete and triangular. First four antennal segments in ratio of 14:4:2:2, segment XI $0.5 \mathrm{x}$ as long as wide. Eye small, with three-four facets, distant from mandible 1.66x its length. Vertex slightly concave medially, corner rounded, occipital carina visible on dorsal view. Gena 0.6x length of head. Mesosoma (Fig. 12) weakly coriaceous, punctures inconspicuous. Pronotal disc $1.30 \mathrm{x}$ as long as wide, anterior margin convex, anterior corner rounded. Mesoscutum $1.35 \mathrm{x}$ as wide as long, posterior margin convex. Propodeal disc flat, $1.66 \mathrm{x}$ as long as posterior width, carina strong and well-defined; spiracle placed at lateral of propodeum, attached to lateral carina. Legs polished to weakly coriaceous, setose, profemur $2.3 \mathrm{x}$ as long as wide, mesotibia without spurs. Metasoma polished, cross section subcircular. Petiole long and strongly coriaceous.

Material examined. Panama, Darién: Cana (Serrania de Pirre, 1250m), 1 male and female in copula, 4-7.vi.96, J. Ashe 


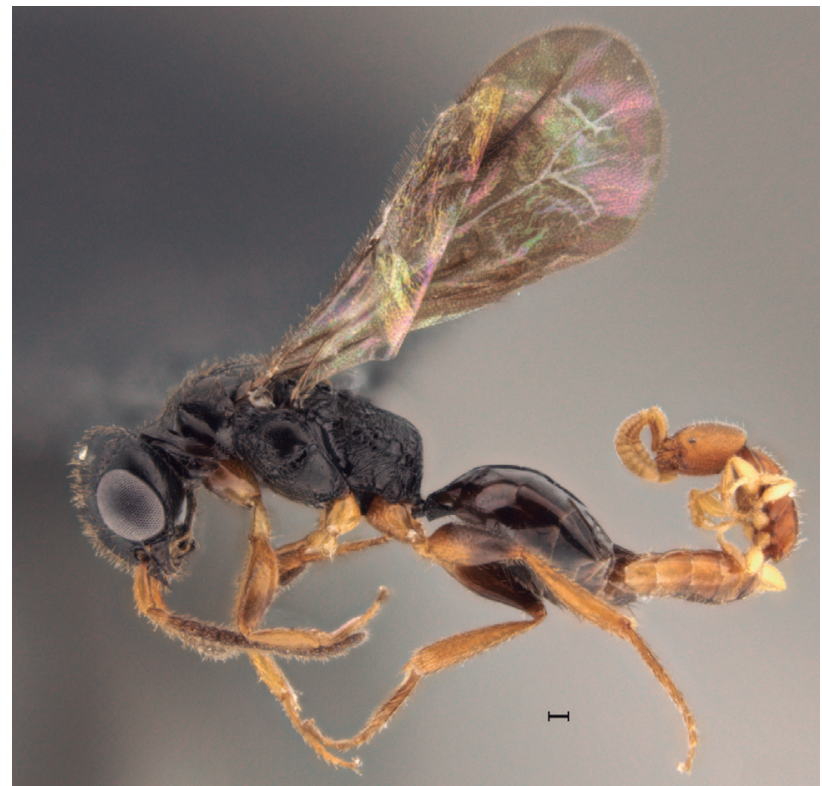

Figure 13. Male and female of Dissomphalus rettenmeyeri from Panama coupled in position of phoretic copulation as during in copula. Scale bars: $100 \mu \mathrm{m}$.

$\&$ R. Brooks leg. (UFES); Chiriqui: (Finca la Suiza, nr. Hornitos), 1 male and female in copula, 2-6.vi.2000, flight interception trap, H. \& A. Howden leg. (UFES).

Remarks. Dissomphalus rettenmeyeri is known only from Panama. The female was described based on a single specimen, which was designated as the allotype by Evans (1964). It was collected from the same locality as the male holotype, but not in copula. Evans (1964) did not explain why he associated the sexes, but it is possible that the fact that male and female were collected from the same place was a factor in the authors' decision. Here we described the first two females of $D$. rettenmeyeri recorded in copula. The allotype was not available to us for examination, and the description provided by Evans (1964), unfortunately, does not include illustrations and is not sufficient to decide whether that specimen really corresponds to $D$. rettenmeyeri or not. We have noticed, and recorded, some variation with respect to the original description, for instance eyes with three or four facets in the specimens available to us, while the allotype has six facets according to its description.

\section{Dissomphalus bisserratus Azevedo, 1999}

Material examined. Bolivia, Cochabamba: Vila Tunari (Estação Biológica Valle del Saita, Universidade San Simón, $\left.17^{\circ} 06.52^{\prime} \mathrm{S}, 64^{\circ} 47.87^{\prime} \mathrm{W}\right), 1$ male and female in copula, 9-13. ii.1999, flight interception trap, R.S. Hanley leg. (CNCI).

Remarks. This species was known from both sexes from Brazil (Distrito Federal and São Paulo, Azevedo 1999). It is now recorded for first time from Bolivia.

\section{Dissomphalus connubialis Evans, 1966}

Material examined. BraziL, Espírito Santo: Alfredo Chaves (S.F. Batatal), 1 male and female in copula, 8.ix.2007, manual, Alencar \& Fraga leg. (UFES).

Remarks. This species was known from both sexes, from Brazil. It is widely distributed in the Brazilian Atlantic Forest. A couple in phoretic copulation was collected by Felipe Fraga at noon, in a house made of wood, and which had galleries built by wood-boring beetles. The house is surrounded by an agroforestry system. Two other couples of the same species were observed flying in copula during the afternoon.

\section{DISCUSSION}

Making sex associations based only on the adult morphology of Aculeate Hymenoptera (Tiphiidae, Bethylidae and Mutillidae) is unfeasible. In order for the researcher to make reliable associations without molecular tools, male and female need to be collected during phoretic copulation. The present study is not the first attempt to associate males and females coupled during flight. Evans (1966) was the first to associate specimens of Dissomphalus using couples in phoretic copulation. He associated males and females of $D$. connubialis from Santa Catarina, Brazil, based on 14 couples (Evans 1966; see Table 1).

VARGAS (2008) studied a couple of D. xanthopus Ashmead, 1893 in phoretic copulation from Kentucky, USA (Table 1). All the main generic characters described for the females by Evans (1966) were found in D. xanthopus. Since then, the females of five other species have been discovered in copula. This work reports $D$. simulatus, $D$. mendicus, $D$. firmus and $D$. rettenmeyeri in phoretic copulation for the first time (Table 1), summing up to thirteen couples of Dissomphalus collected in copula.

Table 1. Species of Dissomphalus with female and male associated by phoretic copulation (in chronological order).

\begin{tabular}{|c|c|c|}
\hline Species & Locality & Reference \\
\hline D. connubialis Evans, 1966 & Brazil, Santa Catarina & Evans 1966 \\
\hline D. bifurcatus Azevedo, 1999 & Brazil, Pará & Azevedo 1999 \\
\hline D. bisserratus Azevedo, 1999 & $\begin{array}{l}\text { Brazil, Distrito Federal } \\
\text { Brazil, São Paulo }\end{array}$ & AzEVEDo 1999 \\
\hline D. megadentatus Azevedo, 2001 & Brazil, Pará & AZEVEDo 2001 \\
\hline D. mirabilis Evans, 1966 & Brazil, Paraná & AzEVEDo 2003 \\
\hline D. xanthopus Ashmead, 1893 & USA, Kentucky & VARGAS 2008 \\
\hline D. uncus Alencar \& Azevedo, 2008 & Venezuela, Aragua & Alencar \& Azevedo 2008 \\
\hline D. bisserratus Azevedo, 1999 & Bolivia, Cochabamba & Present study \\
\hline D. connubialis Evans, 1966 & Brazil, Espírito Santo & Present study \\
\hline D. firmus Redighieri \& Azevedo, 2006 & Brazil, Espírito Santo & Present study \\
\hline D. mendicus Evans, 1969 & Brazil, Distrito Federal & Present study \\
\hline D. rettenmeyeri Evans, 1964* & Panama, Darien & Present study \\
\hline D. simulatus (Evans, 1969) & Bolivia, Cochabamba & Present study \\
\hline
\end{tabular}

*Female already described by Evans (1964), but not in copula.

Insect mating systems and male mate seeking behaviors have been the subject of a number of reviews (e.g., THORNHILL \& 
Alcock 1983, Osten 1999, Choe \& Crespi 1997, Strassmann 2001, PAXTON 2005). Yet, the mechanism triggered during flight and which promotes coupling is poorly discussed in the literature. We observed the coupling mechanism in the species of Dissomphalus. During copula, the female genitalia of the four species had the same structural arrangement. The sting sets in the central portion of the genitalia; it surpasses the genital ring and two lobes, the first and the second valvifers, which are responsible for conducting poison through the sting (SNODGRASS 1941). The second valvifer is located beside the sting and is shorter than the genital ring. The first valvifer is the outermost and is smaller than the second valvifer; it does not reach the genital ring of the male genitalia when in copula. During copulation, the last segment of the male's metasoma envelops the last two segments of the female's metasoma. The genital paramere of the male bends outward, being held by the female's pleurite. The last dorsal tergite of the female is positioned on the dorsal region of the male's genitalia. The volsella is bent and its muscles grasp the female'stergite. A similar coupling mechanism was described for Apenesia nitida Evans, 1969, another Pristocerinae, by GoRdH (1990). During flight, the female is suspended venter-up from the tip of the male's metasoma. The male mounts the female and upon flight, the female flips backward into a venter-up position (Evans 1969). We did not observe, in Dissomphalus, the aedeagal clasps described by Evans (1969) as occurring in females of $A$. nitida. These, structures would grasp the male aedeagus during copula. However, the females may have some muscular grasping mechanism to hold the ventral ramus of the aedeagus but because the musculature is removed by diaphanization, it is inconspicuous or completely destroyed in the studied specimens. In the male, the aedeagal apodeme goes up, bending the dorsal body of the aedeagus toward the ventral region and to the base of the sting, probably near the opening of the spermatic chamber; the same was described for $A$. nitida (Evans 1969). The latter author pointed out that the aedeagus changes in size and shape during copula. However, he was not able to study the modifications in shape after copulation. We recorded post-copulatory intraspecific variation in the genital structures. In the couples we analyzed there were minor differences in the shape of the dorsal body, especially at the apex, but the size of this structure remained the same. The ventral ramus was observed only in ventral or dorsal position. There are no conspicuous interspecific differences in the female genitalia of Dissomphalus. It is possible that the female genitalia has not been subjected to selection constrains by the phoretic copulation, whereas greater selection pressure has been exerted on the stinging mechanism.

Dissomphalus, as well as the other Hymenoptera, have special features for phoretic copulation. The parameres embrace the outside of the apical segment of the female, the volsellar processes (digitus and cuspis) are associated with holding the margin of the apical segment, and the aedeagus is thrust deeply into the female, its tip presumably in or near the spermathecal opening. The sting of the female is retracted, even though it is capable of great extension. Since the insects are connected only by their genitalia during phoretic copulation, it is possible that the genitalia of the male and female become tightly coupled (Fig. 13). The structural divergences in the male genitalia of Dissomphalus have been used to justify new species based on the lock-and-key hypothesis, which allow mating and dispersal success during flight. Concluding, sexual association in Dissomphalus can only be made when couples are collected during intercourse. Dissomphalus species have slightly different copulatory mechanisms from those seen in Apenesia.

Finally, collecting couples in copula is a great way to improve the taxonomy of Dissomphalus, since females have reduced structures that make their identification and association with the other sex difficult. The morphology of the female is poorly studied and needs to be investigated. Providing key for the females of Dissomphalus is challenging since they vary only in the shape of the head, mandibular teeth, and shape of the median clypeal lobe. Lastly, studies based on couples captured during phoretic copulation in Mutillidae (QueIroz et al. 2006), Tiphiidae (Osten 1999) and Bethylidae (Evans 1969, GordH 1990, VARGAS 2008) show the difficulties in performing the sexual association and the importance of integrating ecological and behavioral data in taxonomic studies.

\section{ACKNOWLEDGMENTS}

We thank J.T. Huber (CNCI) and R.C. Mendonça (IBGE) for the loan of specimens, and anonymous reviewers that improved this manuscript. COA thanks CNPq (Conselho Nacional de Desenvolvimento Científico e Tecnológico) for researcher fellowship, grant 305746/2014-6; WDC and CDB thanks CAPES (Coordenação de Aperfeiçoamento de Pessoal de Nível Superior) for Master scholarship; IDCCA thanks CAPES for Doctoral scholarship; and CW thanks to FAPES (Fundação de Amparo à Pesquisa e Inovação do Espírito Santo)/CAPES for postdoctoral fellowship, grant 71026436.

\section{LITERATURE CITED}

Alencar IDCC, Azevedo CO (2008) A new species-group of Dissomphalus (Hymenoptera: Bethylidae), with description of thirteen new species. Zootaxa 1851: 1-28.

Azevedo CO (1999) Revision of the Neotropical Dissomphalus Ashmead, 1893 (Hymenoptera, Bethylidae) with median tergal processes. Arquivos de Zoologia 35: 301-394.

Azevedo CO (2001) Systematics of the Neotropical Dissomphalus Ashmead (Hymenoptera, Bethylidae) of the bicavatus group.

Revista Brasileira de Entomologia 45: 173-205.

Azevedo CO (2003) Synopsis of the Neotropical Dissomphalus (Hymenoptera, Bethylidae). Zootaxa 338: 1-74.

Choe JC, CRespi BJ (1997) The Evolution of Mating Systems in Insects and Arachnids. Cambridge, Cambridge University Press, 400p. 
Evans HE (1964) A synopsis of the American Bethylidae (Hymenoptera, Aculeata). Bulletin of the Museum of Comparative Zoology 132: 1-222.

Evans HE (1966) Further studies on Neotropical Pristocerinae (Hymenoptera, Bethylidae). Acta Hymenopterologica 2: 99-117.

Evans HE (1969) Phoretic copulation in Hymenoptera. Entomological News 80: 113-124.

Gordh G (1990) Apenesia evansi sp. nov. (Hymenoptera: Bethylidae) from Australia with comments on phoretic copulation in bethylids. Journal of Australian Entomology 29: 167-170.

HARRIS RA (1979) A glossary of surface sculpturing. Occasional Papers in Entomology 28: 1-31.

Mugrabi DF, Azevedo CO (2013) Revision of Thai Dissomphalus Ashmead, 1893 (Hymenoptera: Bethylidae), with description of twenty-four new species. Zootaxa 3662: 1-73. doi: 10.11646/ zootaxa.3662.1.1

OsTen T (1999) The phoretic copulation of Thynninae in an ecological and evolutionary perspective (Hymenoptera, Tiphiidae). Linzer Biologische Beiträge 31: 755-762.

Paxton RJ (2005). Male mating behaviour and mating systems of bees: an overview. Apidologie 36: 145-156.

Queiroz-G E, Cambra R, Melo GAR (2006) Sexual associations for two species of mutillid wasps (Hymenoptera, Mutillidae), with the description of a new species of Anomophotopsis. Revista Brasileira de Entomologia 50: 379-384. doi: 10.1590/ S0085-56262006000300007

Sawada H, Terayama M, Mita T (2014) New species of Neoapenesia (Hymenoptera: Bethylidae) from Japan, with special remarks on female morphology and bionomics. Entomological Science 17: 324-329.
SNODGrass RE (1941) The male genitalia of Hymenoptera. Smithsonian Miscellaneous Collections 99: 1-86.

STRASSMANN JE (2001) The rarity of multiple mating in the social Hymenoptera. Insectes Sociaux 48: 1-13.

Terayama M (2001) Descriptions of seven new species of the genus Dissomphalus Ashmead (Hymenoptera, Bethylidae) from the Oriental Region. Japanese Journal of Systematic Entomology 7: 81-90.

Thornhill R, Alcock J (1983) The Evolution of Insect Mating Systems. Cambrigde, Harvard University Press, 564p.

VARGAS JM (2008) First record of phoretic copulation in Dissomphalus xanthopus Ashmead (Hymenoptera: Bethylidae). Entomological News 118: 470-474. doi: 10.3157/0013-872X(2007)118[470:FROPCI]2.0.CO;2

Submitted: 29 April 2016

Received in revised form: 1 August 2016

Accepted: 8 August 2016

Editorial responsibility: Ângelo Parise Pinto

Author Contributions: COA WDC CW conceived the idea; COA WDC IDCCA CDB collected and analyzed the data; COA WDC IDCCA CDB and CW wrote the paper.

Competing Interests: The authors have declared that no competing interests exist. 